\title{
Rancang Bangun Sistem Informasi Eksekutif pada STMIK STIKOM Indonesia
}

\author{
I Nyoman Tri Anindia Putra ${ }^{* 1}$, Ketut Sepdyana Kartini ${ }^{2}$ \\ 1,2 Teknik Informatika, STMIK STIKOM Indonesia, Denpasar, Indonesia
}

\author{
A R T I C L E I N F O \\ Article history: \\ Received 19 July 2019 \\ Received in revised form \\ 16 August 2019 \\ Accepted 19 September \\ 2019 \\ Available online 30 October \\ 2019 \\ Kata Kunci: \\ Sistem Informasi Eksekutif, \\ Monitoring, Sistem \\ Informasi \\ Keywords: \\ Executive Information \\ System (EIS), Monitoring, \\ Information System
}

\begin{abstract}
A B S T R A K
Sistem Informasi Eksekutif dapat dikatakan sebagai suatu sistem yang dapat membantu eksekutif dalam menentukan keputusan yang diperlukan, keterangan laporan yang dihasilkan oleh sistem, serta menyediakan akses informasi yang mudah dan baik dari luar maupun dari dalam yang bertujuan untuk mempermudah organisasi tertentu dalam menyelesaikan suatu kendala. Sistem informasi eksekutif yang dirancang telah dapat memudahkan bidang sarana prasarana tentunya dalam memonitoring kegiatan kinerja yang dilakukan oleh staff teknisi pada STMIK STIKOM Indonesia berdasarkan kuesioner oleh eksekutif terkait yaitu kepala bidang sarana dan prasarana STMIK STIKOM Indonesia, serta pengujian secara blackbox untuk fungsionalitas dari sistem informasi yang telah dibuat memperoleh hasil 100\% berdasarkan sistem berjalan dengan baik sesuai dengan fungsinya.
\end{abstract}

\section{A B S T R A C T}

Executive Information System can be said as a system that can help executives in determining the decisions needed, statement information generated by the system, as well as providing easy and easy access to information from outside or inside that aims to facilitate certain organizations in resolving an obstacle The executive information system that was designed has been able to facilitate the field of infrastructure facilities, of course, in monitoring the performance activities carried out by the technical staff at STMIK STIKOM Indonesia based on a questionnaire by the relevant executives, namely the head of the facilities and infrastructure of STMIK STIKOM Indonesia and blackbox testing for the functionality of the information system that has been made to get $100 \%$ results based on the system running well according to its function.

Copyright (@) Universitas Pendidikan Ganesha. All rights reserved.

\footnotetext{
* Corresponding author.

E-mail addresses: trianindiaputra@gmail.com (I Nyoman Tri Anindia Putra)
} 


\section{Pendahuluan}

Dalam era industri 4.0 yang sedang berjalan saat ini, segala kegiatan yang dilakukan baik dalam bidang pendidikan, sosial, sampai dengan budaya segala sesuatunya telah terintegrasi dengan teknologi. Mulai dari memulai aktivitas di pagi hari sampai dengan malam hari. Segala sesuatunya dilakukan tanpa kita sadari telah bergantung dengan teknologi. Perkantoran merupakan salah satu tempat yang tidak luput dari teknologi itu sendiri bahkan teknologi digunakan untuk membantu menyelesaikan berbagai urusan perkantoran mulai dari laporan sampai dengan pekerjaan yang sangat rumit dapat diselesaikan dengan mudah dengan adanya sentuhan teknologi. STMIK STIKOM Indonesia merupakan salah satu institusi yang berkecimpung di dunia pendidikan perguruan tinggi dimana sekolah tinggi yang akrab disebut dengan nama STIKI ini sudah terbiasa menyelesaikan administrasinya dengan menggunakan sentuhan teknologi untuk memperlancar segala proses yang ada, namun dalam hal ini belum semua aspek tersentuh oleh teknologi salah satunya adalah bidang sarana prasarana. Bidang ini memiliki pekerjaan diantaranya memonitoring seluruh inventarisasi sarana dan prasarana yang ada pada STMIK STIKOM Indonesia.

Selain itu juga pada bidang ini terdapat juga pekerjaan untuk memonitoring kinerja dari staff teknisi dalam melakukan pekerjaan sehari hari. Untuk monitoring inventarisasi sudah terdapat sentuhan teknologi berupa sistem informasi yang mampu mempermudah kepala sarana prasarana dalam memonitoring seluruh inventaris yang ada pada STMIK STIKOM Indonesia, namun masih kewalahan dalam memonitoring kinerja dari staff teknisi baik dalam pelaporan kinerja yang telah dilakukan serta bukti pekerjaan yang telah dilakukan oleh teknisi masih bersifat manual sehingga mempersulit perekapan managemen file kinerja teknisi di akhir semester. Menurut Marta dan Agushinta (2012) Informasi merupakan hal yang sangat penting bagi manajemen di dalam pengambilan keputusan. Informasi merupakan hasil proses data yang beragam yang telah dibentuk sedemikan rupa sehingga sesuai dengan permintaan pengguna. Data adalah kumpulan angka maupun karakter yang mempunyai arti tertentu dan diambil dari realita atau kenyataan yang terjadi pada suatu lokasi. Menurut Fatoni dkk (2019) informasi eksekutif adalah suatu data yang diproses dan akan memberikan nilai arti serta bermanfaat, data yang diproses digunakan sebagai bahan keputusan seorang eksekutif untuk alat keterangan yang pasti dalam membuat kesimpulan. Sistem eksekutif berfungsi meyediakan kumpulan informasi untuk pengguna eksekutif disuatu organisasi guna membantu mengidentifikasi, menentukan pilihan putusan permasalahan serta memahaminya. Menurut Prayitno (2017) Sistem Informasi Eksekutif menampilkan informasi berupa dashboard, yakni laporan berbentuk grafik atau tabel yang mudah dipahami dan dimengerti. Dengan metode Drill Down, laporan dapat ditampilkan menjadi lebih spesifik dan mendetail. Selain itu, diperlukannya sistem berbasis web agar pihak eksekutif dapat mengakses sistem informasi eksekutif pemasaran dimanapun mereka berada dan lebih praktis. Menurut Radistya (2014) Sistem informasi eksekutif adalah satu jenis dari manajemen informasi sistem dimaksud untuk memudahkan dan mendukung keterangan dan pembuatan keputusan kebutuhan dari eksekutif senior dengan menyediakan kemudahan akses terhadap keduanya internal dan eksternal keterangan relevan untuk bertemu golongan strategis organisasi. Ini biasanya dipertimbangkan sebagai satu bentuk dikhususkan dari satu sistem mendukung keputusan. Penekanan dari sistem informasi eksekutif berada diatas peraga grafis dan mudah untuk pergunakan interface pemakaian. Sistem informasi ini sangat penting karena sistem informasi berbasis komputer ini dapat memberikan informasi kepada eksekutif untuk mendukung pengambilan keputusan dalam hal menentukan strategi dan kebijakan organisasi. Di samping itu sesuai dengan dinamika bisnis dan persaingan antar perusahaan yang ketat menyebabkan eksekutif membutuhkan informasi yang cepat dan akurat. Menurut Oktarina dkk (2010) Sistem Informasi Eksekutif adalah salah satu tipe sistem informasi berbasis komputer yang ditujukan untuk memfasilitasi kebutuhan informasi yang berkaitan dengan tercapainya tujuan suatu organisasi bagi. Sistem informasi eksekutif merupakan sistem yang dapat mempermudah eksekutif dalam menentukan keputusan berdasarkan data laporan penunjang yang telah disimpan guna dijadikan acuan dalam mengambil keputusan tertentu. Berdasarkan hal tersebut penulis merancang bangun sistem informasi eksekutif untuk membantu kepala bidang sarana dan prasarana dalam memonitoring segala kegiatan atau pekerjaan yang dilakukan oleh staff teknisi sehingga kepala sarana prasarana mampu membantu menentukan keputusan berdasarkan laporan yang dihasilkan dalam sistem informasi eksekutif tersebut. Sistem Informasi Eksekutif (EIS) terkadang disebut sebgai sistem pendukung eksekutif (Executive Support System atau ESS). Sistem ini merupakan sistem Informasi yang menyediakan fasilitas yang fleksibel bagi manajer dan eksekutif dalam mengakses infromasi eksternal dan internal yang berguna untuk mengidentifikasi masalah atau mengenali peluang. Sistem Informasi (SI) merupakan suatu sistem di dalam organisasi yang berhubungan dengan pengolahan transaksi harian, bersifat manajerial dan kegiatan strategis suatu organisasi serta menyediakan pihak luar dengan laporan yang diperlukan. Sistem Informasi Eksekutif merupakan sistem untuk mendukung 
keputusan yang membantu eksekutif tingkat atas menganalisa, membandingkan informasi yang penting sehingga bisa memonitoring dan mengidentifikasi peluang serta masalah. Sistem Informasi Eksekutif dapat membantu eksekutif mengakses data internal sehingga mampu membuat keputusan yang tepat dan sesuai dengan tujuan organisasi mereka. Sistem informasi digunakan unutuk membantu organisasi dalam mengelola berbagai proses bisnis agar berlangsung secara cepat dan akurat. Sistem informasi diterapkan dalam berbagai bidang misalnya untuk mengelola administrasi dipondok pesantren mahasiswa, mengelola sistem e- 2 learning di sekolah, maupun untuk pemantauan presensi siswa di sekolah menggunakan SMS Gateway.

Standar sarana dan prasarana pendidikan tinggi merupakan salah satu dari delapan standar pendidikan yang harus disiapkan oleh Badan Standar Nasional Pendidikan (BSNP) berdasarkan amanat yang dituangkan dalam UU RI Nomor 20 Tahun 2003 tentang Sistem Pendidikan Nasional dan PP Nomor 19 Tahun 2005 tentang Standar Nasional Pendidikan. Standar sarana dan prasarana ini disusun untuk lingkup pendidikan vokasi yang diselenggarakan oleh akademi, politeknik, sekolah tinggi, institut, dan universitas. Standar sarana dan prasarana ini mencakup: a. kriteria minimum sarana yang terdiri dari perabot, peralatan pendidikan, media pendidikan, buku dan sumber belajar lainnya, teknologi informasi dan komunikasi, serta perlengkapan lain yang wajib tersedia untuk menunjang proses pembelajaran yang teratur dan berkelanjutan, b. kriteria minimum prasarana yang terdiri dari lahan, bangunan, ruang-ruang, dan instalasi daya dan jasa yang wajib tersedia untuk menunjang proses pembelajaran yang teratur dan berkelanjutan. Menurut Kamus Besar Bahasa Indonesia. Sarana adalah segala sesuatu yang dapat dipakai sebagai alat dalam mencapai maksud atau tujuan. Sedangkan Menurut Kamus Besar Bahasa Indonesia. Prasarana adalah segala sesuatu yang merupakan penunjang utama terselenggaranya suatu proses usaha, pembangunan proyek dan lain sebagainya. Untuk lebih memudahkan membedakan keduanya. Sarana lebih ditujukan untuk benda-benda yang bergerak seperti komputer dan mesin-mesin, sedangkan prasarana lebih ditujukan untuk benda-benda yang tidak bergerak seperti gedung.

\section{Metode}

Kegiatan pengumpulan data dilakukan dengan mencari data-data sistem informasi yang ada dan mengumpulkan data berupa database-database yang digunakan pada masing-masing sistem informasi.

Pada pengumpulan wawancara, peneliti melakukan wawarncara kepada bidang sarana dan prasarana dan pembantu ketua yang bertanggung jawab atas kinerja dari teknisi yang ada pada STMIK STIKOM Indonesia.

Melakukan studi literatur untuk mendapatkan acuan dalam melakukan perancangan desain skema database untuk mengintegrasi sistem informasi.

Tabel 1. Kebutuhan Sistem Informasi Eksekutif

\begin{tabular}{cl}
\hline No. & \multicolumn{1}{c}{ Kebutuhan Sistem } \\
\hline 1 & Dapat mencatat segala kegiatan yang dilakukan dimanapun \\
2 & Dapat mengetahui pekerjaan harian, mingguan, dan bulanan dari teknisi \\
3 & Dapat mengetahui bukti pekerjaan berupa foto \\
4 & Dapat mengetahui grafik pekerjaan yang telah dilakukan \\
5 & Dapat di review dimana saja oleh bidang sarana dan prasarana terkait monitoring kinerja teknisi. \\
6 & Dapat membuat laporan secara langsung terkait kinerja teknisi \\
7 & Sistem dapat digunakan oleh bidang sarana prasarana dan teknisi \\
8 & Sistem mampu menampilkan data kinerja teknisi baik berupa chart, diagram dan sebagainya. \\
& \\
9 & bidang sarana prasarana mampu melakukan review atau mengecek segala sesuatu yang \\
10 & dimasukan kedalam sistem \\
11 & Sistem mampu mencetak laporan kinerja teknisi perbulannya \\
\hline
\end{tabular}

Dari masalah yang telah diuraikan maka dibutuhkan suatu analisis dan desain dari sistem informasi monitoring guna menyelesaikan permasalahan yang telah dipaparkan. Adapun kebutuhan data dalam perancangan ini yaitu wawancara yang telah dilakukan dalam bentuk kebutuhan sistem yang telah di deskripsikan dalam bentuk use case.Use Case merupakan salah satu bagian dari unified modeling language yang digunakan untuk mendeskripsikan sistem yang akan dibuat. Berikut use case yang telah dibuat untuk membuat sistem informasi monitoring dapat dilihat pada Gambar 1. 


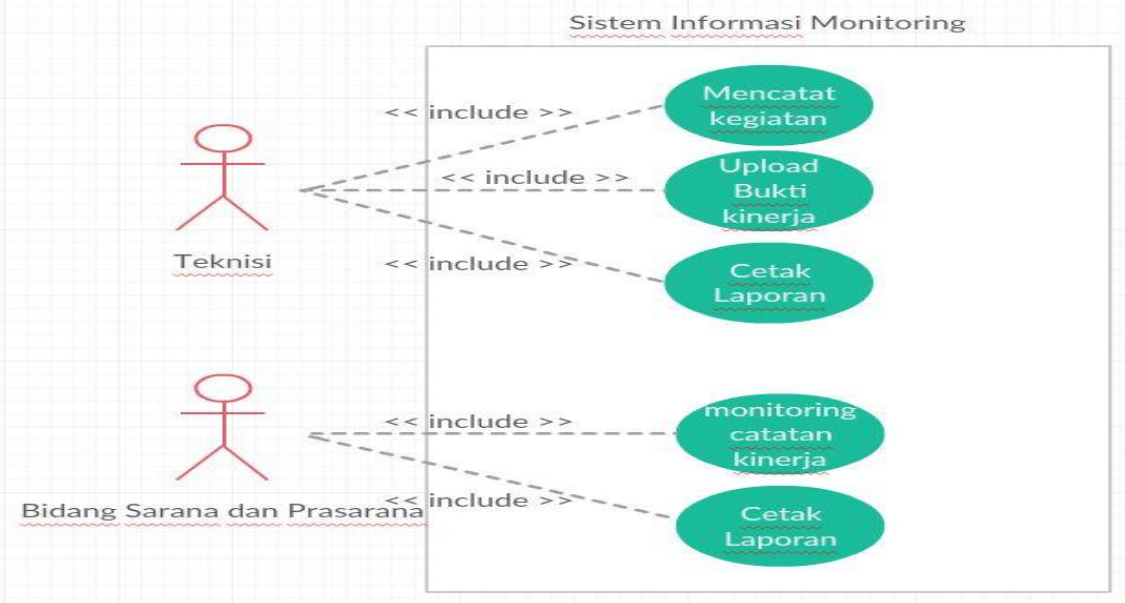

Gambar 1 Use Case

Kebutuhan akan data sistem informasi secara lengkap diperoleh dari pihak STMIK STIKOM Indonesia berdasarkan wawancara dengan pihak terkait berupa kebutuhan sistem yang ditampilkan pada Tabel 1.

Gambaran umum dalam merancang desain database dapat dilihat dalam Gambar 2 memberikan gambaran tentang 3 komponen utama dari sistem yang dibangun yaitu input, proses dan output. Input dari sistem adalah data kumpulan sistem informasi yang dimiliki STMIK STIKOM Indonesia dan data kumpulan database yang terkait dengan masing-masing sistem informasi. Data tersebut dianalisis menurut kebutuhan data setiap sistem informasi hingga menghasilkan sebuah desain terstruktur dari database yang dapat terintegrasi dengan semua sistem informasi tersebut.

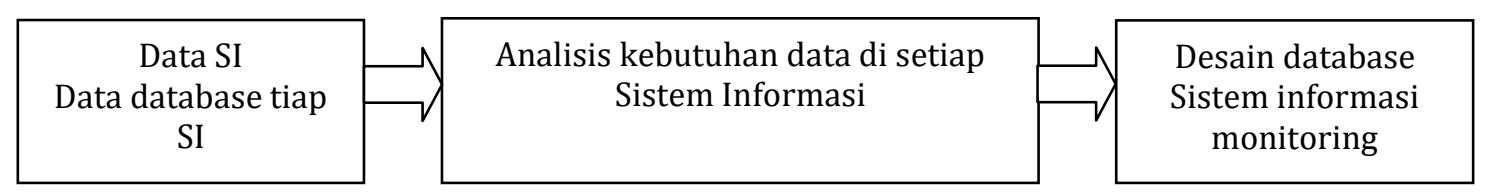

Gambar 2. Perancangan Desain Database

\section{Hasil dan Pembahasan}

Hasil dari antarmuka sistem pada penelitian ini dapat dilihat pada gambar 3. dimana konten yang telah di analisis dan design serta telah di implementasikan pada sistem yang ada dibuat berdasarkan kebutuhan sistem yang telah dicatat saat proses wawancara.

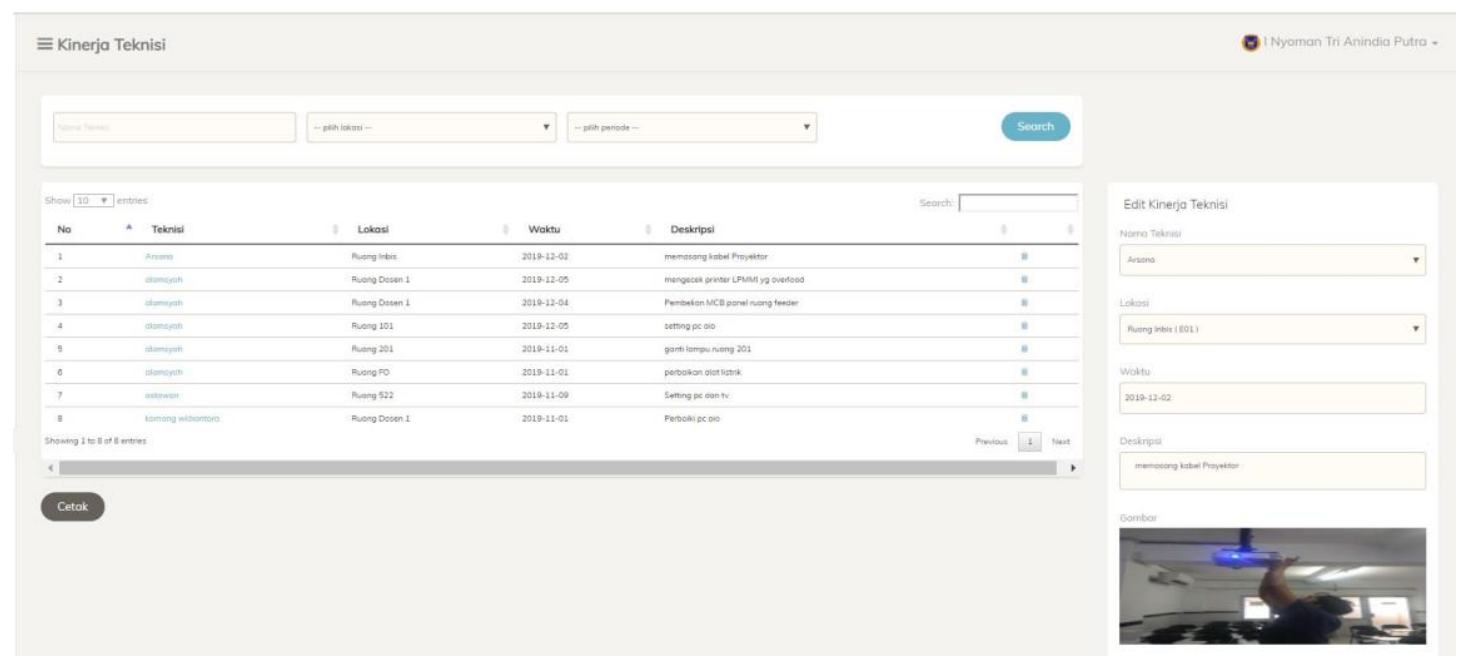

Gambar 3. Interface Dasboard Kinerja Teknisi 
Pada interface 3 terdapat pilihan search untuk memilih periode kinerja teknisi berdasarkan harian, mingguan, dan bulanan. Selain itu dapat juga melihat bukti kinerja dari teknisi yang telah dilakukan saat proses teknisi melakukan pekerjaan.

Untuk melakukan penambahan kinerja dari teknisi dapat dilakukan dengan cara memasukan data pada field edit kinerja teknisi dengan memasukan data sesuai dengan pekerjaan yang dilakukan serta memasukan bukti berupa gambar telah melakukan pekerjaan. Dapat dilihat pada Gambar 4

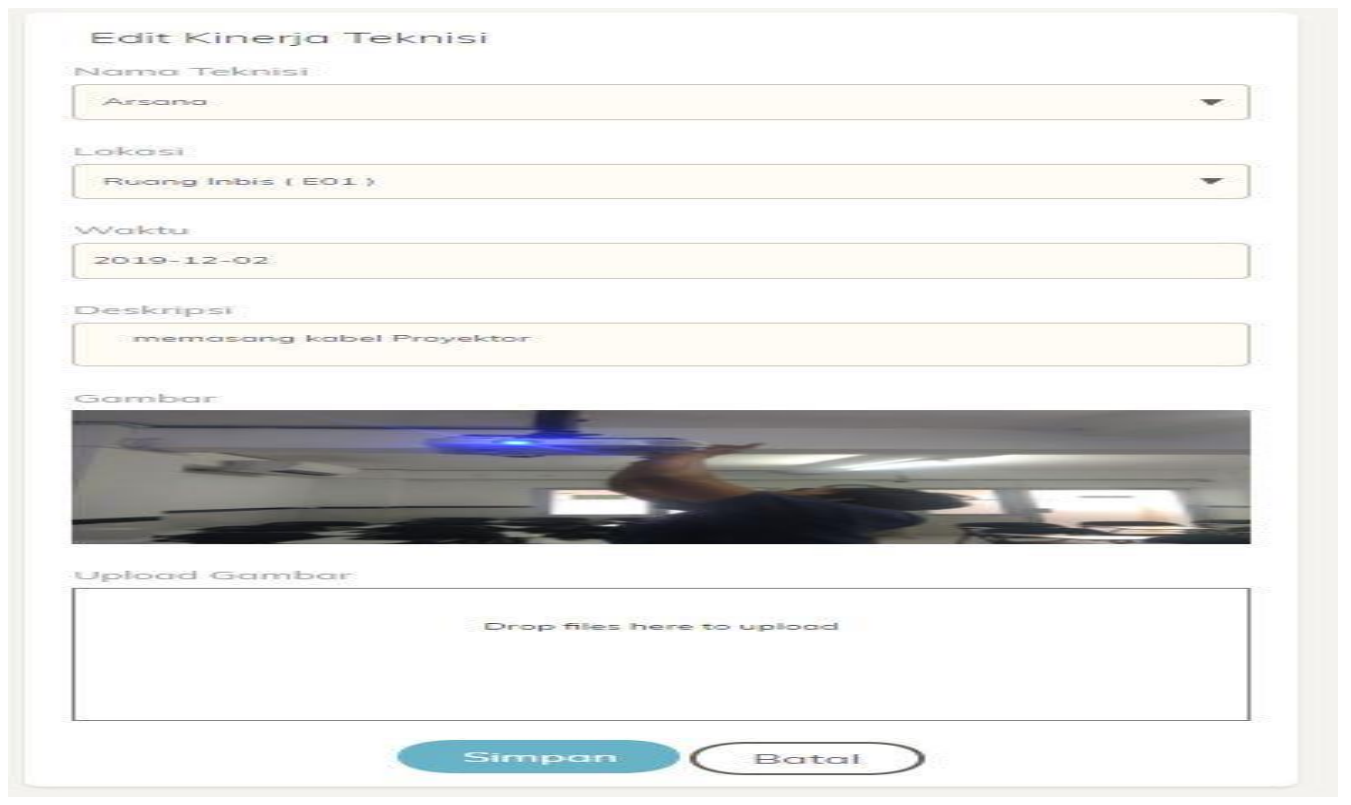

Gambar 4 Input Kinerja Teknisi

Setelah dilakukan pencatatan secara digital pada sistem, akan terdapat grafik yang mempermudah proses monitoring oleh bidang sarana prasarana dalam pengecekan jumlah kinerja yang dilakukan oleh teknisi secara periodik dapat dilihat pada Gambar 5.

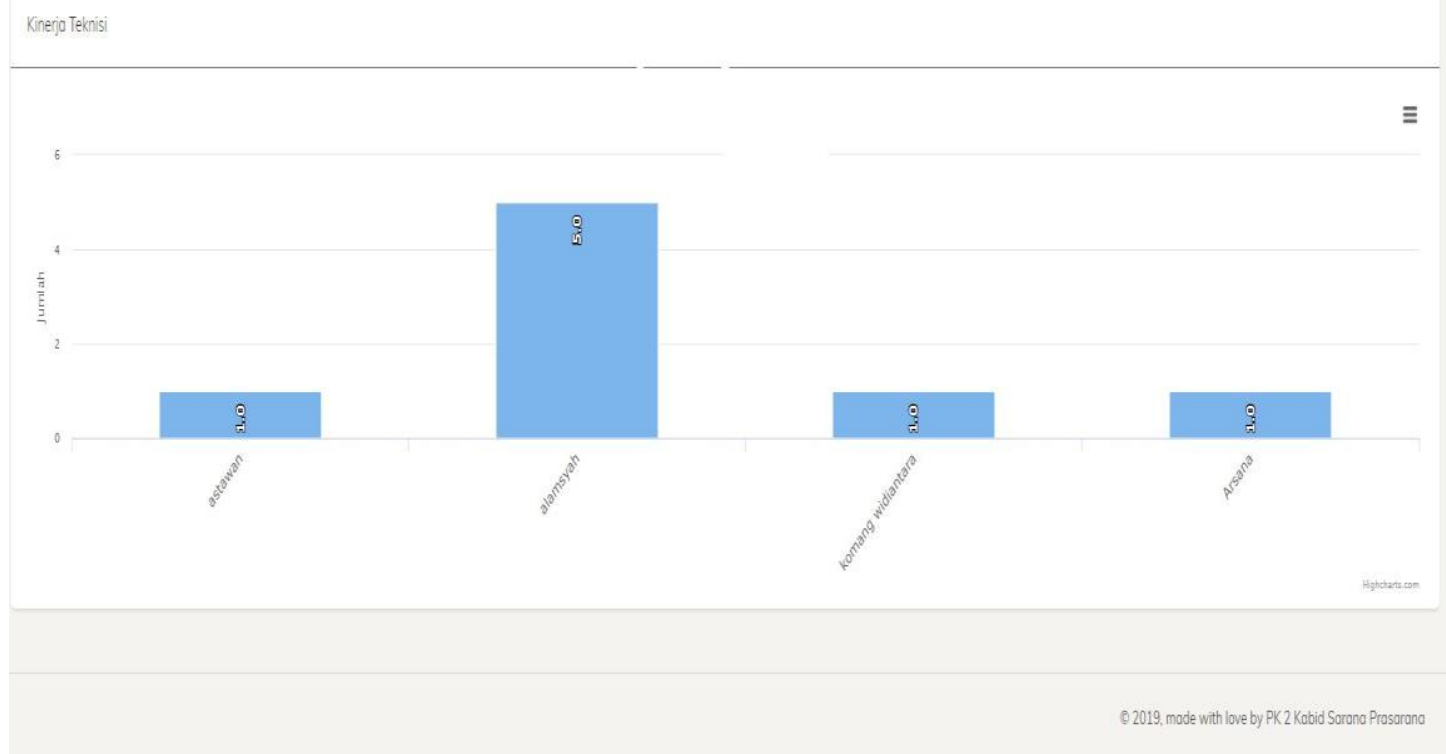

Gambar 5. Grafik Kinerja Teknisi

Dan untuk mempermudah proses pelaporan dan dokumentasi kinerja teknisi sistem mampu melakukan proses pencetakan laporan yang bertujuan untuk mempermudah bidang sarana prasarana dalam melakukan dokumentasi kinerja teknisi. Cetak laporan kinerja teknisi dapat dilihat pada Gambar 6 
LAPORAN KINERJA TEKNISI

\begin{tabular}{|c|c|c|c|l|}
\hline NO. & TEKNISI & LOKASI & WAKTU & \multicolumn{1}{|c|}{ DESKRIPSI } \\
\hline 1 & Arsana & Ruang Inbis & $2019-12-02$ & memasang kabel Proyektor \\
\hline 2 & alamsyah & Ruang Dosen 1 & $2019-12-05$ & $\begin{array}{l}\text { mengecek printer LPMMI yg } \\
\text { overload }\end{array}$ \\
\hline 3 & alamsyah & Ruang Dosen 1 & $2019-12-04$ & $\begin{array}{l}\text { Pembelian MCB panel ruang } \\
\text { feeder }\end{array}$ \\
\hline 4 & alamsyah & Ruang 101 & $2019-12-05$ & setting pc aio \\
\hline 5 & alamsyah & Ruang 201 & $2019-11-01$ & ganti lampu ruang 201 \\
\hline 6 & alamsyah & Ruang FO & $2019-11-01$ & perbaikan alat listrik \\
\hline 7 & astawan & Ruang 522 & $2019-11-09$ & Setting pc dan tv \\
\hline 8 & komang widiantara & Ruang Dosen 1 & $2019-11-01$ & Perbaiki pc aio \\
\hline
\end{tabular}

Gambar 6 Laporan Cetak Kinerja Teknisi

Pengujian sistem merupakan suatu kegiatan atau proses yang dilakukan untuk memastikan apakah fungsi dan atribut pada sistem telah bekerja dengan baik dan berfungsi sesusai dengan harapan. Pengujian sistem ini dilakukan dengan cara menguji beberapa fungsi dari sistem antara lain.

Tabel 2. Skenario Pengujian Halaman Kinerja Teknisi

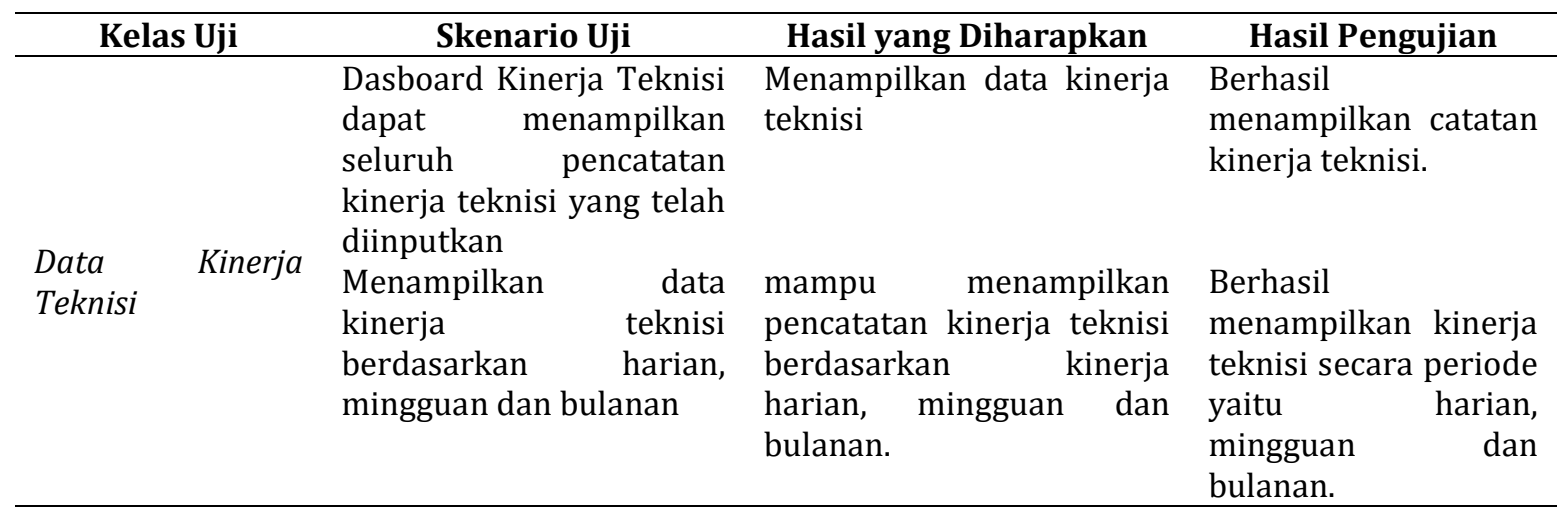

Tabel 3. Skenario Pengujian Pencatatan Kinerja Teknisi ke sistem

\begin{tabular}{|c|c|c|c|}
\hline Kelas Uji & Skenario Uji & Hasil yang Diharapkan & Hasil Pengujian \\
\hline \multirow{2}{*}{$\begin{array}{l}\text { Data Kinerja } \\
\quad \text { Teknisi }\end{array}$} & $\begin{array}{l}\text { Memasukan data kinerja } \\
\text { teknisi pada sistem }\end{array}$ & $\begin{array}{l}\text { Mampu menyimpan segala } \\
\text { pencatatan kinerja teknisi }\end{array}$ & $\begin{array}{l}\text { Berhasil } \\
\text { menyimpan } \\
\text { pencatatan kinerja } \\
\text { teknisi }\end{array}$ \\
\hline & $\begin{array}{l}\text { Melakukan proses Upload } \\
\text { bukti kinerja teknisi pada } \\
\text { sistem }\end{array}$ & $\begin{array}{l}\text { Mampu menyimpan bukti } \\
\text { proses kinerja teknisi }\end{array}$ & $\begin{array}{l}\text { Berhasil } \\
\text { menyimpan bukti } \\
\text { proses kinerja } \\
\text { teknisi }\end{array}$ \\
\hline
\end{tabular}

Tabel 4. Skenario Pengujian Grafik Kinerja Teknisi

\begin{tabular}{|c|c|c|c|}
\hline Kelas Uji & Skenario Uji & Hasil yang Diharapkan & Hasil Pengujian \\
\hline \multirow[t]{2}{*}{$\begin{array}{c}\text { Data Kinerja } \\
\text { Teknisi }\end{array}$} & 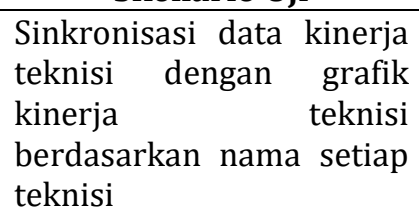 & $\begin{array}{l}\text { Sistem mampu sinkronisasi } \\
\text { data kinerja teknisi dengan } \\
\text { grafik yang ada pada sistem }\end{array}$ & $\begin{array}{l}\text { Berhasil sinkronisasi } \\
\text { data kinerja teknisi } \\
\text { dengan grafik pada } \\
\text { sistem }\end{array}$ \\
\hline & $\begin{array}{l}\text { Sistem menampilkan } \\
\text { grafik kinerja teknisi }\end{array}$ & $\begin{array}{l}\text { Sistem mampu } \\
\text { menampilkan grafik kinerja } \\
\text { teknisi }\end{array}$ & $\begin{array}{l}\text { Berhasil menampilkan } \\
\text { grafik kinerja teknisi }\end{array}$ \\
\hline
\end{tabular}


Tabel 5. Skenario Pengujian Cetak Laporan

\begin{tabular}{|c|c|c|c|c|}
\hline Kelas Uji & Skenario Uji & Hasil yang Dih & Irapkan & Hasil Pengujian \\
\hline \multirow{3}{*}{$\begin{array}{l}\text { Data Kinerja } \\
\text { Teknisi }\end{array}$} & Sistem mampu cetak & \multirow{3}{*}{$\begin{array}{l}\text { Sistem mampu } \\
\text { laporan teknisi } \\
\text { Sistem } \\
\text { menampilkan } \\
\text { kinerja teknisi }\end{array}$} & \multirow[t]{2}{*}{ mencetak } & \multirow{2}{*}{$\begin{array}{l}\text { Berhasil mencetak } \\
\text { laporan kinerja teknisi }\end{array}$} \\
\hline & laporan kinerja teknisi & & & \\
\hline & $\begin{array}{l}\text { Menampilkan } \\
\text { kinerja teknisi }\end{array}$ & & $\begin{array}{l}\text { mampu } \\
\text { laporan }\end{array}$ & $\begin{array}{l}\text { Berhasil menampilkan } \\
\text { laporan kinerja teknisi }\end{array}$ \\
\hline
\end{tabular}

\section{Simpulan dan Saran}

Berdasarkan Penelitian yang telah dilakukan terhadap permasalahan yang ada yaitu pengecekan kinerja teknisi oleh bidang sarana dan prasarana ditengah padatnya pekerjaan lainnya, dapat diminimalisir dengan menggunakan sistem informasi eksekutif untuk monitoring kinerja teknisi melalui bukti foto kinerja teknisi, sehingga dapat membantu bidang sarana prasarana dalam pengecekan kinerja teknisi tanpa harus terjun langsung untuk melakukan pengecekan terhadap pekerjaan yang telah dilakukan oleh teknisi.

Adapun saran yang dapat diberikan peneliti pada penelitian kali ini :1) Dalam menyelesaikan permasalahan tidak perlu terlalu rumit dan menggunakan metode yang sulit untuk menyelesaikan permasalahan yang ada; 2) Pencatatan digital dapat dilakukan untuk memperpudah permasalahan managemen yang sering dihadapi oleh banyak instansi, namun dibutuhkan sistem informasi yang cerdas untuk dapat membantu eksekutif dalam menentukan langkah setelah seluruh data dapat dimanagemen dengan baik, salah satunya adalah dengan memanfaatkan metode pengambilan keputusan untuk membantu eksekutif dalam mengambil keputusan tertentu.

\section{Daftar Rujukan}

Azad, M. M., Amin, M. B., \& Alauddin, M. (2012). Executive Information System. International Journal of Computer Science and Network Security (IJCSCS), 12(5), 106.

B. E. C and D. Manggiasih, "PENJUALAN BERBASIS WEBSITE PADA PT . GRAHA CELLULAR PRATAMA PALEMBANG," pp. 1-7.

Cano Giner, J. L. (2013). What groups of factors do senior executives believe affect their use of executive information system.

Devri Radistya. 2014. 'Sistem Informasi Eksekutif Lingkungan Kementerian Keuangan', Sekolah Tinggi Akuntansi Negara, p. 40. Available at: https://www.academia.edu/7252681/Sistm _Informasi_Eksekutif_Kemenku

Fadlilah, U. (2016). Rancang Bangun Website dan E-Learning di TPQ Al-Fadhillah. Khazanah Informatika. Jurnal Ilmu Komputer dan Informatika, 1.

Fatoni, Edi Supratman, Darius Antoni. 2019. Kerangka Kerja Sistem Informasi Eksekutif Perguruan Tinggi. Jurnal Teknologi Informasi dan Ilmu Komputer (JTIIK) Vol. 6, No. 3, Hal. 257-266. Tersedia Pada: http://jtiik.ub.ac.id/index.php/jtiik/article/view/946/pdf.

Martha, Edy, Dewi Agushinta R. 2012. Analisis dan Perancangan Sistem Informasi Eksekutif Studi Kasus pada Sekretariat Kabinet. Seminar Nasional Teknologi Informasi dan Komunikasi Hal. 31-35. Tersedia Pada: https://fti.uajy.ac.id/sentika/publikasi/makalah/2012/2012-1.pdf.

Oktarina, Vina. Wibisono, Yudi. Waslaluddin. 2010. "Executive Information Systems di Organisasi Sekolah Menengah Atas". Kumpulan Skripsi Pendidikan ILKOM UPI. Hal: 31-35.

P. Ilmiah, A. J. I. H. Purnomo, P. S. Informatika, F. Komunikasi, D. A. N. Informatika, and U. M. Surakarta, "Sistem informasi eksekutif pada sistem informasi pengembangan sumber daya manusia universitas muhammadiyah surakarta," 2017.

Prayitno, M. Hadi. 2017. Sistem Informasi Eksekutif Pemasaran Dengan Metode Drill Down. Jurnal Kajian Ilmiah 105 Universitas Bhayangkara Jakarta Raya Volume 17, No. 3, Hal. 105-110. Tersedia Pada: 
Pradessya, R.A., Saputro, N. A., \& Supriyono, H. (2016). Rancang Bangun Sistem Informasi Manajemen Presensi Berbasis SMS Gteway (Studi Kasus: SMP Muhammadiyah 1 Kartasura).The 3rd University Research Coloquium, ISSN 2407-9189.

Thamrin, H. (2012). Model Pengembangan Sistem Informasi Pengelolaan Pondok Pesantren Mahasiswa. Prosiding SNATIKA Vol 01 (2011), 1(01).

Wulandari, A. F., \& Yamasari, Y. (2012). SISTEM INFORMASI MANAJEMEN SUMBER DAYA MANUSIA (STUDI KASUS BUMIDA SYARIAH). Jurnal Manajemen Informatika. 